\title{
In Vivo Micrografting to Eliminate Passiflora Latent Virus from Infected Passion Fruit Plants
}

\author{
Tatsushi Ogata* and Shinsuke Yamanaka
}

Tropical Agriculture Research Front, Japan International Research Center for Agricultural Sciences, Ishigaki 907-0002, Japan

An in vivo micrografting method was developed to obtain Passiflora latent virus (PLV)-free passion fruit from infected plants. The scion length required to eliminate PLV was $\leq \mathbf{2 m m}$. The method required no aseptic handling and the procedure was relatively simple, and resulted in more than 10 micrografts in one hour. Moreover, no special equipment or procedures were necessary, allowing it to be conducted at an individual farm level. Rapid growth of the scion after grafting was also observed due to the use of fully established seedlings as rootstock. Leaf samples for analysis of PLV infection could therefore be obtained about two months after grafting with fruit harvest possible about four months later. In vivo micrografting was conducted with a scion length of $0.5-1 \mathrm{~mm}$ from September to November to determine the optimal air temperature conditions. The graft success rate increased from $18 \%$ to $58 \%$ with a decrease in the average air temperature from September $\left(28.6^{\circ} \mathrm{C}\right)$ to November $\left(23.3^{\circ} \mathrm{C}\right)$, although there was no significant difference in PLV-free rates between months (73\% to $80 \%)$. Accordingly, in vivo micrografting of passion fruit is not recommended under high air temperature conditions. The effect of scion shoot storage conditions was also examined, revealing that in vivo micrografting using shoots stored for one day could be performed without difficulty, whereas the rate of graft success and PLV-free rate were close to those obtained using shoots selected less than $\mathbf{3 0}$ min before. These findings suggest that with this method, virus-free plants can be obtained using PLV-infected shoots selected in the field one day earlier. In conclusion, our in vivo micrografting technique is useful to eliminate PLV from infected plants; it is simple and leads to rapid growth of the scion after grafting.

Key Words: Passiflora edulis Sims, tropical fruit, virus-free.

\section{Introduction}

Passion fruit (Passiflora edulis Sims) is the third most important tropical fruit produced in Japan after pineapple and mango. Plants have of a woody vine that grows rapidly under warm humid conditions, with fruit harvest possible about five months after planting. Commercial cultivation of passion fruit is therefore possible without heating, even in temperate regions where survival is not possible during the cold winter months. As a result, cultivation of passion fruit is gaining increasing attention in Japan to replace crops which are getting difficult to cultivate due to climate change.

In Japan, most passion fruit vines grown for fresh consumption are hybrid cultivars with characteristics that suit the Japanese market. Purple passion fruit taste good, but their fruit are small, while yellow passion

Received; October 15, 2020. Accepted; February 13, 2021.

First Published Online in J-STAGE on April 17, 2021.

* Corresponding author (E-mail: ogata@affrc.go.jp). fruit, which have larger fruit, are too acidic for fresh consumption. In contrast, hybrid cultivars such as 'Ruby Star', 'Tainung No. 1', and 'Summer Queen' have a more palatable taste and larger fruit than purple passion fruit, and are therefore relatively popular in Japan. As with many fruit trees, these hybrid passion fruit cultivars are propagated vegetatively in order to maintain their characteristics. However, vegetative propagation increases the risk of virus infection compared with seed propagation because none of the viruses found in Passiflora spp. are known to be transmitted by seeds (Manicom et al., 2003; Fischer and Rezende, 2008). Passion fruit is at risk of a number of viruses (Singh, 2004; Fischer and Rezende, 2008), and in Japan, where vines are replanted every one or two years, the risk of virus dissemination through propagation is higher than that of perennial fruit trees, which are replanted every decade or so.

In the 1990s, several years after the introduction of hybrid cultivars, the passion fruit industry in Kagoshima prefecture, Japan, was seriously damaged 
by passion fruit woodiness virus (PWV) (Iwai et al., 1996, 2006), one of the most economically damaging viruses affecting passion fruit (Manicom et al., 2003; Fischer and Rezende, 2008). To eliminate the disease, a propagation system was established using healthy stock plants grown in isolated greenhouses, followed by certification as East Asian Passiflora virus (a PWV strain found in Kagoshima)- and Passiflora latent virus (PLV)free using an enzyme-linked immunosorbent assay test before distribution (Iwai and Omatsu, 2002). However, this system does not exist in other areas of Japan, so virus dissemination as a result of vegetative propagation remains a concern.

In 2017, a field survey of 84 passion fruit farms in Okinawa prefecture, one of the most important passion fruit producing areas in Japan, revealed PLV infection in $85.7 \%$ of the farms (Ajitomi et al., 2018). Identification of infected plants based on appearance alone is not easy because PLV induces no symptoms or inconspicuous systemic foliar mosaic symptoms only (Pares et al., 1997). PLV infections can therefore spread widely undetected. The effect of PLV on passion fruit production is currently unknown (Pares et al., 1997; Fischer and Rezende, 2008), although a recent report suggested that co-infection with PLV and cucumber mosaic virus causes more severe symptoms than single infections (Muramoto and Suzuki, 2020). Control, or elimination, of PLV infections in Japan is therefore important.

Control and elimination of viral diseases requires propagation from healthy virus-free stock. However, in some areas, all cultivated local hybrid passion fruit plants test positive for PLV infection (personal communication), preventing propagation of PLV-free plants. In this study, we developed a new in vivo micrografting method that allowed production of PLV-free passion fruit plants from infected stock, providing healthy stock for propagation.

\section{Materials and Methods}

\section{Scion plants}

One-year-old passion fruit plants ('Summer Queen' and 'Ishigaki No. 2') infected with PLV were used as the scion source. These cultivars have a green leaf vein with a tinge of purple. Two plants per cultivar were grown in $20-\mathrm{L}$ pots in a greenhouse using a mixture of peat moss, sand, and rice husk charcoal $(1: 1: 1)$ as a potting media. Liquid fertilizer $(\mathrm{N}: \mathrm{P}: \mathrm{K}=15: 6: 6)$ was applied with irrigation water (1:1000) once every day.

\section{Rootstock preparation}

Yellow passion fruit seedlings planted in 0.5 -L plastic pots in a greenhouse were used as rootstock. Seedlings had a green leaf vein color that differed from that of the scion plants. The potting media was a mixture of peat moss, sand, and rice husk charcoal (1:1:1). Plants were cultivated in the same way as scion plants without using scissors or knives to avoid infection.
When they reached a height of approximately $50 \mathrm{~cm}$ (about two months after sowing), plants were used as rootstock for micrografting.

\section{In vivo micrografting}

The method for in vivo micrografting was modified from that of Takahara et al. (1986). Briefly, vigorously growing shoots about $10 \mathrm{~cm}$ long were pinched off from scion plants, stripped of large leaves then stored in polyethylene bags until use. The top of each rootstock plant was cut at the softwood part, about $10 \mathrm{~cm}$ from the shoot apex, then a 1-2-mm-long half-cylinder section of the cut end was removed using a razor blade (Fig. 1A). After removing young leaves and leaf primordia from the scion shoot using a toothpick (Fig. 1B), the shoot-tip was then excised using a small piece of blade broken from a carbon steel razor blade and attached to a surgical handle as a scalpel, then transferred to the rootstock using a fresh toothpick. The length of the excised shoot tip ranged from 0.5 to $1 \mathrm{~mm}$ unless otherwise specified. The excised shoot-tip (scion) was placed in contact with the vascular ring (cambium) on the bottom of the L-shaped cut end of the rootstock (Fig. 1C). The micrograft was then covered with laboratory film to prevent drying. Shoot-tip excision and transfer were carried out using a head-mounted binocular loupe at $\times 3.5$ magnification. To avoid virus transfer from infected to uninfected tissues, the razor blade and toothpick were replaced during each micro-
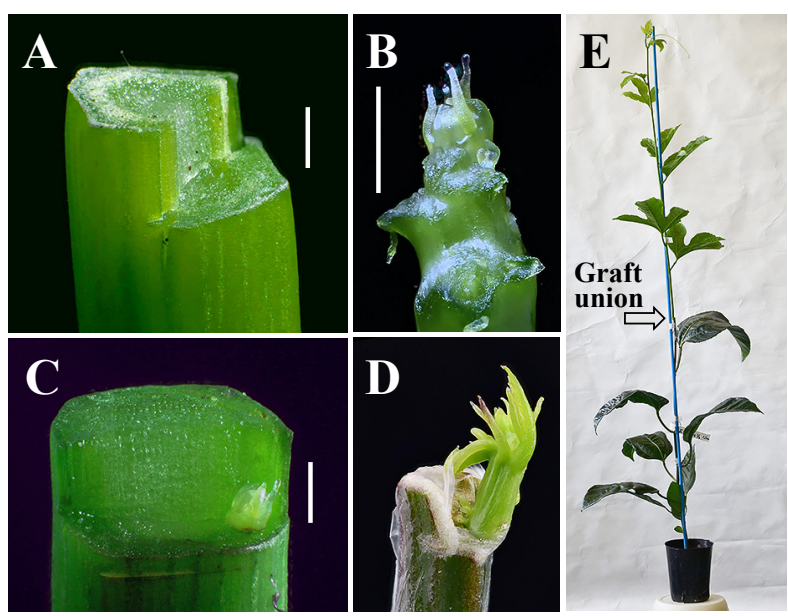

Fig. 1. In vivo micrografting of passion fruit. A: A 1-2-mm-long half-cylinder section of the cut end of a rootstock was removed using a razor blade. B: The shoot-tip used as a scion, with young leaves and leaf primordia removed before excision. C: The cambium on the L-shaped cut end of the rootstock to which the excised shoot-tip (scion) was attached. The graft was then covered with laboratory film to prevent drying. D: Sprouting of the scion about one month after in vivo micrografting. The sprouting scion self pierced the laboraltory film, so removal of the the film was not necessary. E: The growing scion about two months after micrografting, ready for virus detection using RT-PCR. Bars in A, B, and C: $1 \mathrm{~mm}$. A, B, C, and $\mathrm{D}$ are focus-stacked images. 
graft. Micrografting was conducted within $30 \mathrm{~min}$ of removing the scion shoots in experiments 1 and 2. In experiment 3, micrografting was conducted one day after scion shoot removal.

\section{Care of grafted plants}

Grafted plants were transferred to a greenhouse soon after micrografting. Axillary shoots arising from the rootstock were pinched off every one to three days, and the condition of the scions (sprouting, alive but not sprouting, or dead) was evaluated once a week until four months after grafting. Buds emerging from the graft point were able to self pierce the laboratory film, so removal of the film was not necessary. Each emerging shoot was identified as a scion or an adventitious shoot differentiated from the rootstock by its leaf vein color as a morphological marker.

\section{Detection of PLV}

Grafted plants were examined for PLV infection by reverse transcription polymerase chain reaction (RTPCR) to detect virus RNA in the leaves of growing plants at least two months after micrografting (Fig. 1E). Total RNA was isolated from both young and old leaves of a single plant by using ISOGEN (Nippon Gene Co., Ltd., Tokyo, Japan) according to the manufacturer's protocol.

RT-PCR was conducted using Ready-to-Go RT-PCR beads (GE-Healthcare Life Sciences, currently Cytiva, Tokyo, Japan) according to the manufacturer's "OneStep protocol for RT-PCR" using the following primers: 5'-GGGCCCTCAAAGCTATAC-3' (reverse transcription), 5'-GCTTCAAGTTCTTCTGAGCC-3' (forward) and 5'-CTTGCAAGCCACCAGTGTAC-3' (reverse). Primers were designed by the Laboratory of Plant Pathology, Faculty of Agriculture, Kagoshima University, Japan, based on Spiegel et al. (2007). The reaction consisted of 1 st strand cDNA synthesis for $30 \mathrm{~min}$ at $42^{\circ} \mathrm{C}$, followed by initial denaturation for $5 \mathrm{~min}$ at $94^{\circ} \mathrm{C}, 25-30$ cycles of denaturation for $1 \mathrm{~min}$ at $94^{\circ} \mathrm{C}$, annealing for $1 \mathrm{~min}$ at $55^{\circ} \mathrm{C}$, and extension for $2 \mathrm{~min}$ at $72^{\circ} \mathrm{C}$, ending in final extension for $10 \mathrm{~min}$ at $72^{\circ} \mathrm{C}$. The amplified products were separated in $2 \%$ agarose gel and 745-bp fragments were identified as PLV-infected (Fig. 2).

\section{Experiment 1: Effect of scion length}

To determine the effect of scion length, in vivo micrografting was conducted using three scion lengths $(1,2-3$, and $5 \mathrm{~mm})$ from September to October 2017. A total of eight, five, and eight grafts were carried out, respectively.

\section{Experiment 2: Effect of grafting time}

To determine the effect of air temperature on grafting time, in vivo micrografting was conducted two or three times a month in September, October, and November

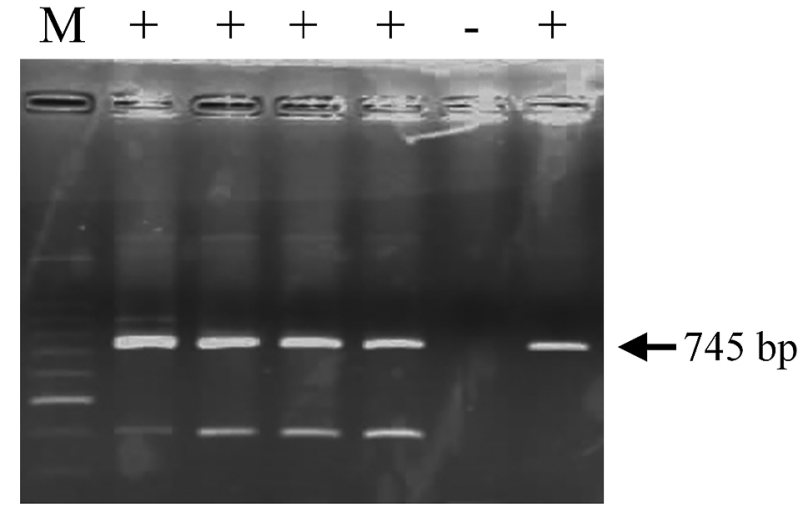

Fig. 2. Results of reverse transcription polymerase chain reaction detection of Passiflora latent virus (PLV) infection. M: $100 \mathrm{bp}$ ladder, +: samples in which PLV was detected. Arrowheads indicate the expected $745 \mathrm{bp}$ fragment of PLV.

2018. The air temperature conditions were different among these months each year. A total of 60,24, and 65 grafts were conducted, respectively. The air temperature in the greenhouse was recorded every $10 \mathrm{~min}$ using a datalogger (Ondotori TR-52; T\&D Corporation, Matsumoto, Japan).

\section{Experiment 3: Effect of scion shoot storage conditions}

To examine the effect of scion shoot storage conditions, shoots of PLV-infected plants were collected around 16:00 in November 2018 then placed in polyethylene bags and stored at either $5^{\circ} \mathrm{C}$ or $25^{\circ} \mathrm{C}$ in the dark. In vivo micrografting was conducted the following day at around 16:00 using the stored shoots as scions. A total of 17 and 18 grafts were performed, respectively.

\section{Results and Discussion}

\section{Experiment 1: Effect of scion length}

Scion length affected the micrografting success rate and elimination of PLV. With a scion length of $\geq 2$ $3 \mathrm{~mm}$, all grafts succeeded; however, some grafts with a scion length of $1 \mathrm{~mm}$ failed (Table 1). PLV-free plants were obtained with a scion length of $\leq 2-3 \mathrm{~mm}$ (Table $1)$.

\section{Experiment 2: Effect of grafting time}

Grafting time also affected the success of micrografting, but not the elimination of PLV. The micrografting success rate increased from September (18\%) to November $(58 \%)$ as the average air temperature decreased from $28.6^{\circ} \mathrm{C}$ to $23.3^{\circ} \mathrm{C}$ (Table 2). We also conducted 70 in vivo micrografts of several cultivars from June to July 2019 when the air temperatures were very high (mean the daily maximum, average and minimum air temperatures were $33.7^{\circ} \mathrm{C}, 29.0^{\circ} \mathrm{C}$, and $26.4^{\circ} \mathrm{C}$, respectively), resulting in a success rate of $17 \%$ (12 successful grafts). These findings suggest that micrografting at high air temperatures decreases the 
overall success rate. In contrast, PLV-free rates were high at $73 \%$ to $80 \%$ and were not significantly different between months (Table 2). Heat therapy is known to effectively eliminate viruses during micrografting and tissue culture in some plants (Nyland and Goheen, 1969; Mori, 1971; Takahara et al., 1986), so micrografting at high air temperatures is similarly thought to have increased the virus-free rate. Thus, a scion length of $0.5-1 \mathrm{~mm}$ may have been small enough to eliminate $\mathrm{PLV}$, even though an average air temperature of $28.6^{\circ} \mathrm{C}$ may be ineffective as heat therapy to decrease PLV concentrations in passion fruit shoot-tips. Therefore, the optimal air temperature conditions for micrografting of passion fruit remain unclear; however, the findings suggest that high air temperature periods with a maximum air temperature of $>30^{\circ} \mathrm{C}$ should be avoided.

\section{Experiment 3: Effect of scion shoot storage conditions}

In vivo micrografting using shoots stored for one day was carried out without difficulty, and the rate of graft success and PLV-free rate were close to those obtained using shoots removed less than $30 \mathrm{~min}$ before grafting (Tables 2 and 3). This finding suggests the potential to obtain PLV-free plants using PLV-infected shoots selected in the field one day earlier. Overall, no statistical differences were found between the two temperature storage conditions (Table 3).

A number of techniques have been developed to eliminate viruses from plants (Hollings, 1965; Panattoni et al., 2013), most of which use thermotherapy, chemotherapy, or tissue culture. In addition to these methods, in vitro micrografting is also used in some woody plants. Murashige et al. (1972) and Navarro et al. (1975) originally suggested that certain pathogens that are difficult to eliminate by thermotherapy, such as the citrus exocortis viroid, could be eliminated by shoot-tip grafting in vitro (in vitro micrografting) using $0.14-0.18$-mm-long shoot-tips as scions. Since then, in vitro micrografting has become widely used in citrus growing countries to produce healthy plants (Juárez et al., 2015).

Use of in vivo micrografting, otherwise known as

Table 1. Effect of scion length on the elimination of Passiflora latent virus (PLV) via in vivo micrografting.

\begin{tabular}{ccccccc}
\hline \hline \multirow{2}{*}{ Scion length $(\mathrm{mm})$} & \multicolumn{3}{c}{ In vivo micrografting } & & \multicolumn{2}{c}{ PLV } \\
\cline { 2 - 3 } \cline { 5 - 6 } & Number of grafts & Successful grafts & Success rate (\%) & & Number of virus-free & Virus-free rate (\%) \\
\hline 1 & 8 & 5 & 63 & 3 & 60 \\
$2-3$ & 5 & 5 & 100 & 2 & 40 \\
5 & 8 & 8 & 100 & 0 & 0 \\
\hline
\end{tabular}

Table 2. Effect of grafting time on grafting succes and elimination of Passiflora latent virus (PLV) via in vivo micrografting.

\begin{tabular}{|c|c|c|c|c|c|c|c|c|c|c|}
\hline \multirow[b]{2}{*}{ Grafting time } & \multicolumn{4}{|c|}{ In vivo micrografting ${ }^{z}$} & \multicolumn{3}{|c|}{ PLV } & \multicolumn{3}{|c|}{ Air temperature $\left({ }^{\circ} \mathrm{C}\right)^{\mathrm{x}}$} \\
\hline & $\begin{array}{c}\text { Number of } \\
\text { grafts }\end{array}$ & $\begin{array}{l}\text { Successful } \\
\text { grafts }\end{array}$ & $\begin{array}{l}\text { Success } \\
\text { rate }(\%)\end{array}$ & $\begin{array}{l}\text { Days to } \\
\text { sprouting }^{y}\end{array}$ & $\begin{array}{c}\text { Number } \\
\text { tested }\end{array}$ & $\begin{array}{l}\text { Number of } \\
\text { virus-free }\end{array}$ & $\begin{array}{c}\text { Virus-free } \\
\text { rate }(\%)\end{array}$ & Max. & Avg. & Min. \\
\hline September & 60 & 11 & 18 & $32 \pm 11$ & 11 & 8 & 73 & 35.9 & 28.6 & 24.9 \\
\hline October & 24 & 8 & 33 & $31 \pm 22$ & 5 & 4 & 80 & 30.4 & 24.4 & 21.1 \\
\hline November & 65 & 38 & 58 & $29 \pm 19$ & 22 & 16 & 73 & 29.0 & 23.3 & 20.1 \\
\hline Fisher's exact test ${ }^{\mathrm{w}}$ & & $* * *$ & & & & NS & & & & \\
\hline
\end{tabular}

${ }^{z}$ Scion length: $0.5-1 \mathrm{~mm}$.

y Average \pm SD.

${ }^{x}$ Mean of the daily air temperatures inside the greenhouse where the scion material was grown.

w ***, and NS indicate significance at $P<0.001$, and no significance, respectively.

Table 3. Effect of scion shoot storage conditions on the elimination of Passiflora latent virus (PLV) via in vivo micrografting.

\begin{tabular}{|c|c|c|c|c|c|c|}
\hline \multirow[b]{2}{*}{ Storage conditions ${ }^{\mathrm{z}}$} & \multicolumn{3}{|c|}{ In vivo micrografting ${ }^{y}$} & \multicolumn{3}{|c|}{ PLV } \\
\hline & $\begin{array}{l}\text { Number of } \\
\text { grafts }\end{array}$ & $\begin{array}{c}\text { Successful } \\
\text { grafts }\end{array}$ & $\begin{array}{c}\text { Success rate } \\
(\%)\end{array}$ & Number tested & $\begin{array}{c}\text { Number of } \\
\text { virus-free }\end{array}$ & $\begin{array}{c}\text { Virus-free rate } \\
(\%)\end{array}$ \\
\hline $5^{\circ} \mathrm{C} 1$ day & 17 & 10 & 59 & 10 & 8 & 80 \\
\hline $25^{\circ} \mathrm{C} 1$ day & 18 & 9 & 50 & 9 & 5 & 56 \\
\hline Fisher's exact test ${ }^{\mathrm{x}}$ & \multicolumn{3}{|c|}{ NS } & \multicolumn{3}{|c|}{ NS } \\
\hline
\end{tabular}

${ }^{z}$ Scions were stored in the dark in polyethylene bags.

y Scion length: $0.5-1 \mathrm{~mm}$.

${ }^{x} \mathrm{NS}$ indicates no significance. 
semi-micrografting or ex vitro micrografting, to eliminate viruses was first demonstrated in citrus plants by Takahara et al. (1986), based on the method developed by Navarro et al. (1975). In vivo micrografting has certain advantages over in vitro techniques; for example, it requires no aseptic handling resulting in a simpler procedure and avoids transplant shock when transplanting from sterile in vitro to in vivo conditions. It is therefore widely used to eliminate citrus viruses in Japan (Ohta et al., 2011; Le et al., 2020), and was also adopted by NARO (National Agriculture and Food Research Organization, Japan) to eliminate viruses and viroids from clean citrus plants prior to certification and distribution as new cultivars (Ohta, 2016).

The in vivo micrografting technique for passion fruit reported in this study is based on the citrus technique developed by Takahara et al. (1986); however, there are some differences, one of which is the condition of the rootstock. Micrografting generally requires the use of very young seedlings as rootstock, obtained about one to two weeks after germination in darkness (Navarro et al., 1975; Takahara et al., 1986; Rehman and Gill, 2015). With our technique, micrografting was possible with ordinary fully established seedlings grown in the light for about two months, and requiring no special treatment. Adventitious shoots can arise from rootstock during in vitro grafting in citrus (Navarro et al., 1975; Juárez et al., 2015), and must be distinguished using morphological markers and removed as early as possible. However, in this study, only one suspected adventitious shoot was removed from more than 200 graft points.

Several methods have been developed to eliminate viruses from passion fruit; however, none are as simple as the method described here. For example, Ribeiro et al. (2008) succeeded in eliminating cowpea aphidborne mosaic virus from sour passion fruit plants via in vivo micrografting using a shoot-tip excised to a length of $0.2-0.4 \mathrm{~mm}$ as the scion. Their method required no aseptic handling but the other procedures were similar to standard in vitro micrografting. Meanwhile, Prammanee et al. (2011) obtained passion fruit woodiness virus-free plants using a tissue culture technique involving the apical meristem of purple passion fruit excised to a length of $2 \mathrm{~mm}$. Tissue culture methods are useful in maintaining disease-free plants, but often involve complicated procedures. In comparison, our in vivo micrografting technique was straightforward, and allowed more than 10 micrografts per hour. Moreover, no special equipment or procedures were required other than the micrografting technique itself, allowing it to be conducted at the individual farm level. Fast growth of the scion after grafting was another advantage of our method because fully established seedlings were used as rootstock. As a result, leaf samples for the virus infection test were obtained about two months after grafting and fruit harvest was possible about four months later. In conclusion, our in vivo micrografting technique is useful to eliminate PLV from infected plants; it is simple and leads to rapid growth of the scion after grafting.

\section{Acknowledgements}

The authors are grateful to Dr. H. Iwai for providing information on the detection of PLV.

\section{Literature Cited}

Ajitomi, A., S. Miyagi, T. Inada, A. Ooshiro, M. Yamashiro, M. Matsumura, N. Ahagon, K. Oshiro, R. Nagahama, K. Medoruma, T. Kajiyama, A. Ooishi, A. Shimoji, M. Tokuyama, K. Kijima, A. Yamaguchi, R. Hosokawa, K. Teramura and H. Iwai. 2018. Occurrence of virus diseases in passion fruit field in Okinawa Prefecture. Jpn. J. Phytopathol. 84 (Suppl. 1): 70-71 (In Japanese).

Fischer, I. H. and J. A. M. Rezende. 2008. Diseases of passion flower (Passiflora spp.). Pest Technol. 2: 1-19.

Hollings, M. 1965. Disease control through virus-free stock. Annu. Rev. Phytopathol. 3: 367-396.

Iwai, H. and N. Omatsu. 2002. Passion fruit woodiness virus in Japan. Plant Protection (Shokubutsu-Boeki) 56: 110-113 (In Japanese)

Iwai, H., T. Ohmori, Y. Kurokawa, T. Muta and K. Arai. 1996. New record of passionfruit woodiness virus in Japan. Ann. Phytopathol. Soc. Jpn. 62: 459-465.

Iwai, H., Y. Yamashita, N. Nishi and M. Nakamura. 2006. The potyvirus associated with the dappled fruit of Passiflora edulis in Kagoshima prefecture, Japan is the third strain of the proposed new species East Asian Passiflora virus (EAPV) phylogenetically distinguished from strains of Passion fruit woodiness virus. Arch. Virol. 151: 811-818.

Juárez, J., P. Aleza and L. Navarro. 2015. Applications of citrus shoot-tip grafting in vitro. Acta Hortic. 1065: 635-642.

Le, M. L., K. Sakai, Y. Mizunoe, Y. Ozaki and A. Wakana. 2020. Evaluation of seedlings from 11 citrus accessions for in vivo micrografting. Hort. J. 89: 1-11.

Manicom, B., C. Ruggiero, R. C. Ploetz and A. Goes. 2003. Diseases of passion fruit. p. 413-441. In: R. C. Ploetz (ed.). Diseases of tropical fruit crops. CAB International, Wallingford.

Mori, K. 1971. Production of virus-free plants by means of meristem culture. Japan Agric. Res. Quart. 6: 1-7.

Muramoto, Y. and T. Suzuki. 2020. Occurrence and control of virus diseases of passion fruit in Gifu Prefecture. Jpn. J. Phytopathol. 86 (Suppl. 1): 60 (Abstract in Japanese).

Murashige, T., W. P. Bitters, T. S. Rangan, E. M. Nauer, C. N. Roistacher and P. B. Holliday. 1972. A technique of shoot tip grafting and its utilization towards recovering virus-free citrus clones. HortScience 7: 118-119.

Navarro, L., C. N. Roistacher and T. Murashige. 1975. Improvement of shoot tip grafting in-vitro for virus free citrus. J. Amer. Soc. Hort. Sci. 100: 471-479.

Nyland, G. and A. C. Goheen. 1969. Heat therapy of virus diseases of perennial plants. Annu. Rev. Phytopathol. 7: 331-354.

Ohta, S. 2016. The methods for elimination and certification of citrus virus and viroid conducted in NARO, Japan. Bull. NARO Inst. Fruit Tree Sci. 21: 53-65 (In Japanese with English abstract).

Ohta, S., T. Kuniga, F. Nishikawa, A. Yamasaki, T. Endo, T. Iwanami and T. Yoshioka. 2011. Evaluation of novel anti- 
viral agents in the elimination of Satsuma dwarf virus (SDV) by semi-micrografting in citrus. J. Japan. Soc. Hort. Sci. 80: 145-149.

Panattoni, A., A. Luvisi and E. Triolo. 2013. Review. Elimination of viruses in plants: twenty years of progress. Span. J. Agric. Res. 11: 173-188.

Pares, R. D., L. V. Gunn, E. N. Keskula, A. B. Martin and D. S. Teakle. 1997. Occurrence of Passiflora latent carlavirus in cultivated and wild Passiflora species in Australia. Plant Dis. 81: 348-350.

Prammanee, S., S. Thumjamras, P. Chiemsombat and N. Pipattanawong. 2011. Efficient shoot regeneration from direct apical meristem tissue to produce virus-free purple passion fruit plants. Crop Prot. 30: 1425-1429.

Rehman, H. U. and M. I. S. Gill. 2015. Micrografting of fruit crops-A review. J. Horticulture 2: 151. DOI: 10.4172/ 2376-0354.1000151.
Ribeiro, L. M., J. R. Peixoto, S. R. M. Andrade, R. S. Fonseca, L. M. Vieira and W. V. S. Pereira. 2008. Ex vitro micrografting aiming the CABMV virus elimination in passion fruit plant. Pesq. Agropec. Bras. 43: 589-594 (In Portuguese with English abstract)

Singh, S. J. 2004. Virus and phytoplasma diseases of passion fruit. p. 269-299. In: S. A. M. H. Naqvi (ed.). Diseases of fruits and vegetables, Vol.2. Kluwer Academic Publishers, Dordrecht.

Spiegel, S., M. Zeidan, I. Sobolev, Y. Beckelman, V. Holdengreber, Y. Tam, M. Bar Joseph, Z. Lipsker and A. Gera. 2007. The complete nucleotide sequence of Passiflora latent virus and its phylogenetic relationship to other carlaviruses. Arch. Virol. 152: 181-189.

Takahara, T., N. Okudai and S. Kuhara. 1986. Elimination of citrus viruses by the semi-micrografting. Bull. Fruit Tree Res. Stn. D8: 13-24 (In Japanese with English abstract). 